Article

\title{
Formation Process of an LDHs Coating on Magnesium Alloy by a $\mathrm{CO}_{2}$ Pressurization Method
}

\author{
Xiaochen Zhang ${ }^{1,2} \oplus$, Jiaoxiang Wang ${ }^{3}$, Chunyan Zhang ${ }^{4}$, Bin Liu ${ }^{1}$, Peng Jiang ${ }^{5}$, Yang Zhao ${ }^{6}$, \\ Bateer Buhe ${ }^{2}$, Tao Zhang ${ }^{6, *}$, Guozhe Meng ${ }^{1}$ and Fuhui Wang ${ }^{6}$ \\ 1 College of Materials Science and Chemical Engineering, Harbin Engineering University, Harbin 150001, \\ China; zxc2013@hrbeu.edu.cn (X.Z.); liubin@hrbeu.edu.cn (B.L.); mengguozhe@hrbeu.edu.cn (G.M.) \\ 2 College of Materials Chemical and Engineering, Heilongjiang Institute of Technology, Harbin 150050, China; \\ zf66@hrbeu.edu.cn \\ 3 Department of Research and Development, Avic Harbin Bearing Co. LTD, Harbin 150000, China; \\ wjx15134544571@163.com \\ 4 Institute of Metal Research, Chinese Academy of Sciences, Shenyang 110016, China; chyzhang@imr.ac.cn \\ 5 School of Mechanical Engineering, Changzhou University, Changzhou 213164, China; dbxb@cczu.edu.cn \\ 6 Corrosion and Protection Division, Shenyang National Laboratory for Materials Science, Northeastern \\ University, Shenyang 110819, China; neursc@mail.neu.edu.cn (Y.Z.); fhwang@mail.neu.edu.cn (F.W.) \\ * Correspondence: zhangtao@mail.neu.edu.cn; Tel.: +86-133-524-86898
}

Received: 29 November 2018; Accepted: 14 January 2019; Published: 15 January 2019

check for updates

\begin{abstract}
The formation process of LDHs (layered double hydroxides) coating on magnesium alloy by the $\mathrm{CO}_{2}$ pressurization method was studied. The micro-structure was observed by OM, SEM and GAXRD. The weighted gain curve, apparent activation energy, and $\mathrm{CO}_{2}$ solubility curve were all calculated by equations. The potentiodynamic polarization curve, hydrogen evolution data, and immersion were analyzed by an electrochemical method. The results show that the LDHs coating was formed layer-by-layer. The formation positions were initially on the $\alpha-\mathrm{Mg}$ phase, and then on the $\beta-\mathrm{Mg}_{17} \mathrm{Al}_{12}$ phase. It was found to be the most compact after $30 \mathrm{~min}$. The LDHs coating began to appear to have severe cracks and holes over time. The formation process of the LDHs coating can be divided into three stages: a rapid growth stage (0-10 $\mathrm{min})$, slow growth stage (10-20 min), and periodic growth stage (30 $\mathrm{min}, 1 \mathrm{~h})$. The apparent activation energies in each of the three stages are $21.78,31.86$ and $34.92 \mathrm{~kJ} \mathrm{~mol}^{-1}$, respectively. The LDHs coating has a compact micro-structure and better anti-corrosion at a pressure of $3 \mathrm{MPa}$, a temperature of $50{ }^{\circ} \mathrm{C}$ and a time of $30 \mathrm{~min}$. The $\mathrm{CO}_{2}$ pressurization promotes a formation reaction rate and achieves a high formation efficiency and good formation stability under the condition of zero pollution.
\end{abstract}

Keywords: magnesium alloy; $\mathrm{CO}_{2}$ pressurization method; LDHs coating; formation process; $\alpha-\mathrm{Mg}$ phase; $\beta-\mathrm{Mg}_{17} \mathrm{Al}_{12}$ phase; micro-structure; anti-corrosion property

\section{Introduction}

Magnesium alloys have extensive development potential in areas such as automobile, aerospace, electronics, medical treatment, and so on. The reason for this attention is due to the excellent performance of magnesium alloys, includes low-density, highly specific strength and stiffness, high-performance thermal conductivity and conductance, as well as excellent biological properties and easy-recycling properties [1]. However, magnesium alloy has poor powers of corrosion resistance. On the one hand, a porous oxide/hydroxide film formed on the surface of the magnesium alloys is unable to protect it from corrosion; on the other hand, the galvanic corrosion tends to be formed in the potential differences of the second, impurity and base phases. In addition, stress corrosion or fatigue, caused by residual internal stress, can accelerate the corrosion of magnesium alloys. 
The potential engineering applications of magnesium alloy are thus hindered, due to this poor corrosion resistance [2-5].

At present, there are two main approaches towards improving the corrosion resistance of magnesium alloy. One is to adjust the composition of magnesium alloys so as to prepare high-purity magnesium alloys [6,7], rare earth magnesium alloys [8-11], and to strengthen the corrosion resistance of the matrix. This material preparation method often requires a complex composition and high costs. Furthermore, alloying may also have a negative effect on its mechanical properties as well as its formability [12-16]. Therefore, surface treatment has so far been one of the most effective and convenient ways for improving corrosion resistance. Common surface treatments of magnesium alloys include micro-arc/anodizing, electroplating/electroless plating, laser surface treatment, chemical conversion treatment, organic coating treatment, surface infiltration treatment, and ion implantation [17-19]. Therein, chemical conversion treatment has been widely applied, due to its properties of low-energy consumption, low cost, simple equipment and easy operation. There are two main chemical conversion treatments, namely chromate and non-chromate treatment. Although chromate chemical conversion treatment has a high-performing corrosion resistance for magnesium alloys, hexavalent chromium $\left(\mathrm{Cr}^{6+}\right)$ has been gradually banned, since it is toxic and harmful for the environment; hence the development of new ways towards chromium-free chemical conversion treatments [20-22]. Chromium-free acid salt treatment includes: phosphate conversion coating [23,24], phosphate-permanganate conversion coating [25-27], stannate conversion coating [28,29], vanadate conversion coating [30,31], cerium conversion coating [32,33], lanthanide conversion coating [34], hydrotalcite surface coating, and so forth [35,36]. Hydrotalcite coating has attracted much attention, due to its unique intercalation structure and its environmentally friendly properties [37-50]. Uan et al. [37-43] has conducted some research on hydrotalcite coatings prepared on magnesium alloys, by adopting a one-step method. $\mathrm{Mg}$-Al-hydrotalcite layered double hydroxides $(\mathrm{LDH})$ coatings were prepared by letting the carbonate/bicarbonate solutions stand at $50{ }^{\circ} \mathrm{C}$ for $24 \mathrm{~h}$. Based on previous research, Uan adopted a two-step method by a $2 \mathrm{~h} \mathrm{CO}_{2}$ and $\mathrm{pH} 11.5$ treatment, to modify the chemical technique. It was found that the formation effect was improved by adjusting the $\mathrm{PH}$ value. However, the time was found to be relatively long, with a complex treatment process. Chen et al. [44-48] studied the preparation of $\mathrm{Mg}-\mathrm{Al}$ hydrotalcite coatings on AZ31 $\mathrm{Mg}$ alloys, by a two-step method. The precursor film had cracks in the initial formation, with the LDH conversion coatings then forming densely and compactly. Although the processing time was shortened to two hours, the formation process was still relatively complex. Zhang et al. $[49,50]$ put forward ion exchange and corrosion resistance properties by preparing MgAl-LDH coatings on $\mathrm{Mg}$ and $\mathrm{Al}$ alloys. There are three main shortcomings of the traditional methods in the preparation of hydrotalcite conversion coatings: a long preparation time is not conducive to the application of continuous industrial production; the introduction of carbonate into carbonate solution artificially requires frequent replenishment or replacement of the solution to maintain the concentration of the carbonate ions, requiring a lot of labor; the formation process is difficult to control. Therefore, solving the three aforementioned issues is the key to improving research on hydrotalcite coating surface treatment.

For this paper, the $\mathrm{CO}_{2}$ pressurization method was used to prepare the $\mathrm{LDH}$ coating on magnesium alloy. The formation process of the LDHs coating was found by analyzing the micro-structure, the weighted gain curve, the apparent activation energy, and the anti-corrosion properties of the LDHs coating. It was found that $\mathrm{CO}_{2}$ pressurization promotes the solubility of $\mathrm{CO}_{2}$ in increasing the aqueous solution, which promotes the formation reaction and stability of the LDHs coating. The LDHs coating was prepared with a pressure of $3 \mathrm{MPa}$, a temperature of $50{ }^{\circ} \mathrm{C}$, and a time of $30 \mathrm{~min}$, where it was found to have a compact micro-structure and better anti-corrosion properties. The $\mathrm{CO}_{2}$ pressurization method achieved a high formation efficiency, good formation stability, and zero pollution. 


\section{Materials and Methods}

The composition percentage of the cast AZ91 magnesium alloy was $8.8 \mathrm{wt} \% \mathrm{Al}, 0.69 \mathrm{wt} \% \mathrm{Zn}$, $0.212 \mathrm{wt} \% \mathrm{Mn}, 0.02 \mathrm{wt} \% \mathrm{Si}, 0.002 \mathrm{wt} \% \mathrm{Cu}, 0.005 \mathrm{wt} \% \mathrm{Fe}$, and $0.001 \mathrm{wt} \% \mathrm{Ni}$. Cast AZ91 alloys were used in our experiment. The cast AZ91D magnesium alloys were cut into $20 \mathrm{~mm} \times 12 \mathrm{~mm} \times 6 \mathrm{~mm}$, and $20 \mathrm{~mm} \times 20 \mathrm{~mm} \times 6 \mathrm{~mm}$ samples, with $2 \mathrm{~mm}$ diameter holes. The samples were ground with \#1000-\#2000-mesh SiC abrasive paper, and ultrasonically cleaned in anhydrous ethanol for $10 \mathrm{~min}$.

$\mathrm{CO}_{2}$ was introduced in deionized water with a flow rate of $1 \mathrm{dm}^{3} \cdot \mathrm{min}^{-1}$ for $20 \mathrm{~min}$, in order to form the $\mathrm{CO}_{3}{ }^{2-} / \mathrm{HCO}_{3}{ }^{-}$ion solution. The $\mathrm{pH}$ of the bath was approximately $4.3[37,38]$. The 12 samples were placed into the sealed formation chamber, and then pressurized to $3 \mathrm{MPa}$ by constantly pumping $\mathrm{CO}_{2}$ gas. The formation temperature was set at $50{ }^{\circ} \mathrm{C}$, and the formation time was controlled at 10, 20, 30, $40 \mathrm{~min}$ and $1 \mathrm{~h}$, respectively. The operation of the LDHs coating preparation is shown in Figure 1.

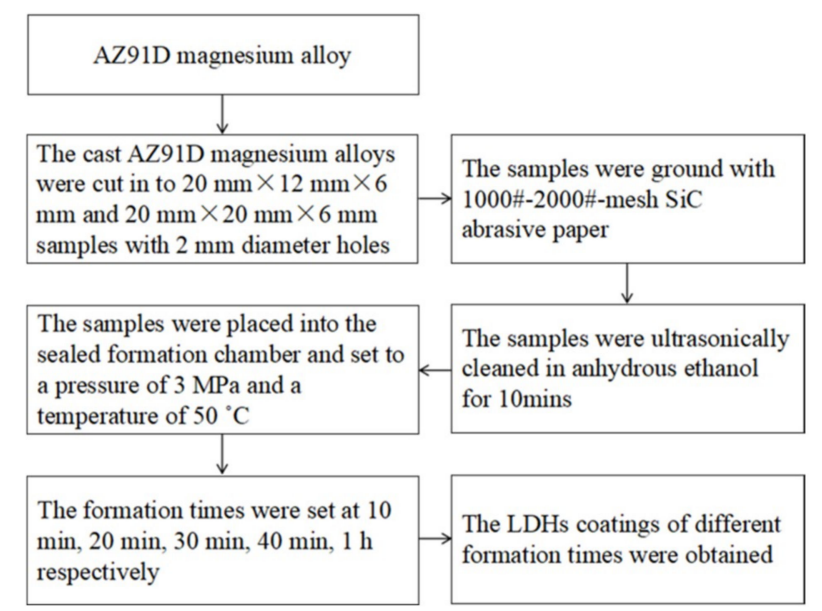

Figure 1. Preparation flowchart of the layered double hydroxides (LDHs) coating prepared by $\mathrm{CO}_{2}$ pressurization.

The morphology and composition of the LDHs coating were analyzed by a scanning electron microscope (SEM) Sigma-500 (Carl Zeiss, Jena, Germany) and grazing angle XRD D8-Discover (GAXRD, Bruker, Stuttgart, Germany) at $\mathrm{Cu} \mathrm{K} \alpha_{1}(1.5405 \AA)$, respectively. The GAXRD is mainly used to determine the diffraction peak of thin film specimens, with the grazing angle $\theta_{\mathrm{s}}$ set within parameters of $5^{\circ}$, and by using small angle accessories to determine the diffraction peak of the sample. The grazing angle used in this experiment was $0.5^{\circ}$.

The weighted gain curve was calculated by using the following method. The samples were weighed by the analytical balance, with it before the treatment being denoted as $W_{0}$. Then, the LDHs coatings were weighed at different periods of processing time, denoted as $W^{\prime}$. The per-unit mass variation of the coating was denoted as $\left(W-W_{0}\right) / S$, which is $(\Delta W / S)$. The size of $S$ for the coating was calculated by accurately measurements. The weighted gain curve can be obtained by the mass variation of the coatings and processing time. The $\mathrm{CO}_{2}$ solubility in deionized water was calculated by the equation of the state from BWRS [51], which has been widely applied with high accuracy.

The Tafel line in 3.5\% NaCl solution was tested by adopting the software 263A M352, based on the Princeton model. A three-electrode system was applied, with a saturated potassium chloride electrode as the reference electrode, the platinum electrode as the supplementary electrode, and the samples as the working electrode. Through using the potentiodynamic scanning method, the samples were sealed by using paraffin, and exposed with a size of $10 \mathrm{~mm} \times 10 \mathrm{~mm}$, a scan rate of $0.333 \mathrm{mV} \mathrm{s}^{-1}$. The corrosion rate was obtained by collecting the volume of hydrogen generated from the reaction in the hydrogen-gathering device. The samples were placed in a beaker containing $3.5 \mathrm{wt} \% \mathrm{NaCl}$ solution, and a water bath pot with a constant temperature $\left(30 \pm 1{ }^{\circ} \mathrm{C}\right)$. The immersion test was conducted 
to determine the corrosion grade of the AZ91D alloy with different times, using the macroscopic corrosion morphologies obtained using a digital camera. For the immersion test, the temperature was set at $30 \pm 1{ }^{\circ} \mathrm{C}$.

\section{Results}

\subsection{Micro-Structure}

The surface and cross-section morphology of the LDHs coatings at different formation times is shown in Figures 2 and 3, respectively. It can be seen that the formation characteristics of the LDHs coating are closely related to the second phase $\left(\beta-\mathrm{Mg}_{17} \mathrm{Al}_{12}\right)$. At higher magnification, the petal-like morphology of the LDHs coating was observed in Figure 2f. The dimensions of the LDHs "particles" are about $0.05 \mu \mathrm{m}$. The result of the GAXRD patterns of the LDHs coatings at different formation times is shown in Figure 4.

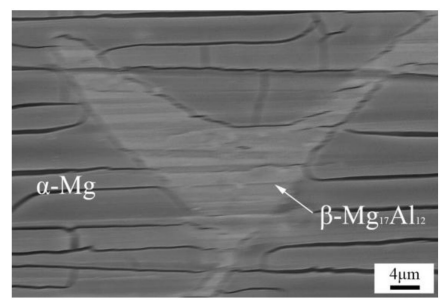

(a)

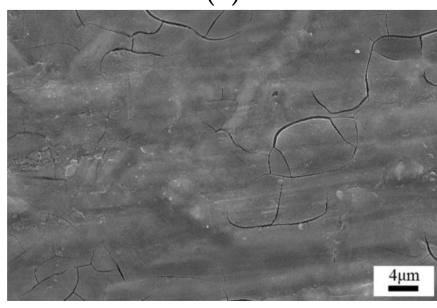

(c)

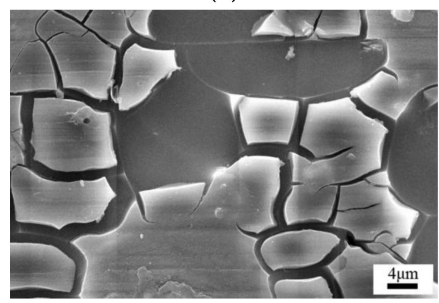

(e)

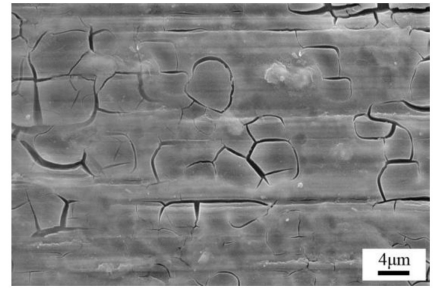

(b)

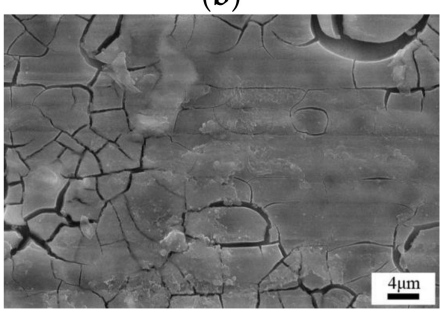

(d)

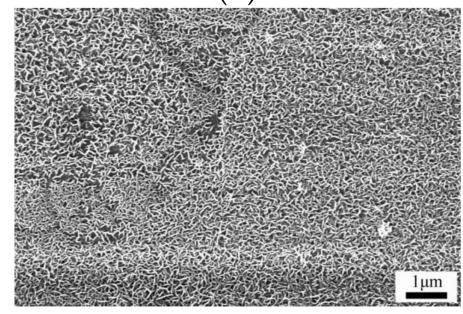

(f)

Figure 2. Surface morphologies of the LDHs coatings at different formation times; (a) $10 \mathrm{~min}$, (b) $20 \mathrm{~min}$, (c) $30 \mathrm{~min},(\mathbf{d}) 40 \mathrm{~min},(\mathbf{e}) 1 \mathrm{~h}$ (f) petal-like at $30 \mathrm{~min}$.

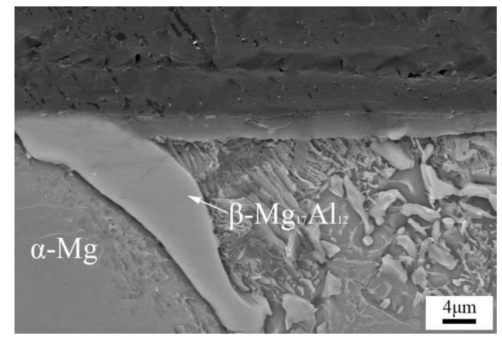

(a)

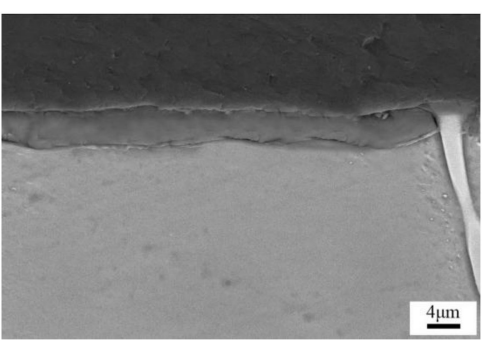

(b)

Figure 3. Cont. 


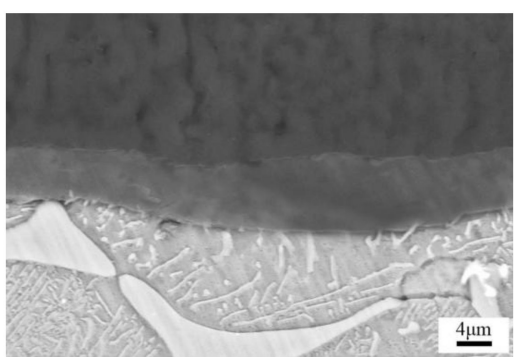

(c)

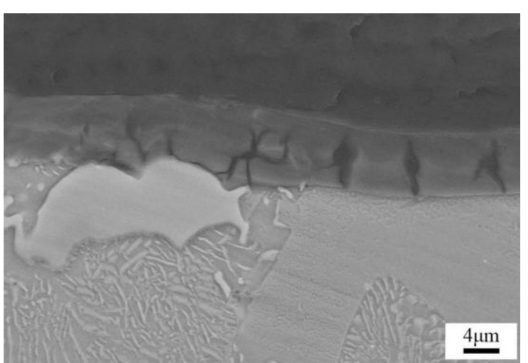

(d)

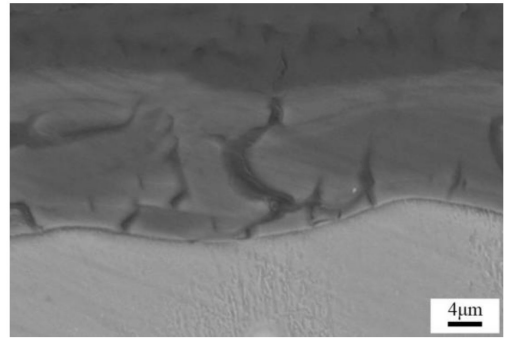

(e)

Figure 3. Cross-sectional morphologies of the LDHs coatings at different formation times; (a) $10 \mathrm{~min}$, (b) $20 \mathrm{~min}$, (c) $30 \mathrm{~min}$, (d) $40 \mathrm{~min}$, (e) $1 \mathrm{~h}$.

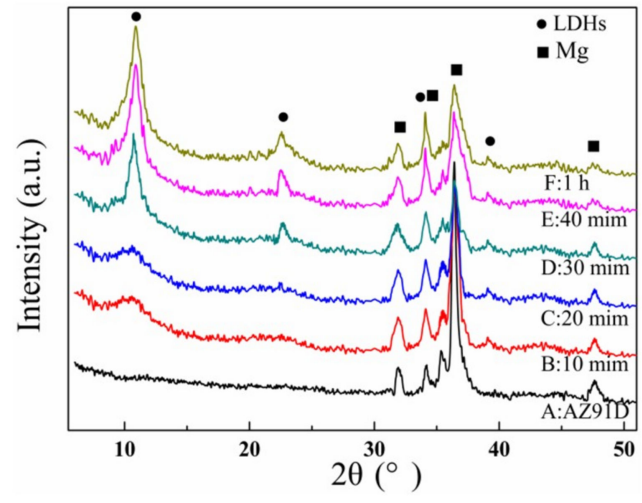

Figure 4. GAXRD patterns of the LDHs coatings at different formation times.

\subsection{Weighted Gain Curve}

The weighted gain curves were obtained in an immersion solution by measuring the relationship between the mass variation per unit coating, and the immersion time. The weighted gain curve of the different growth stages can be seen in Figure 5.

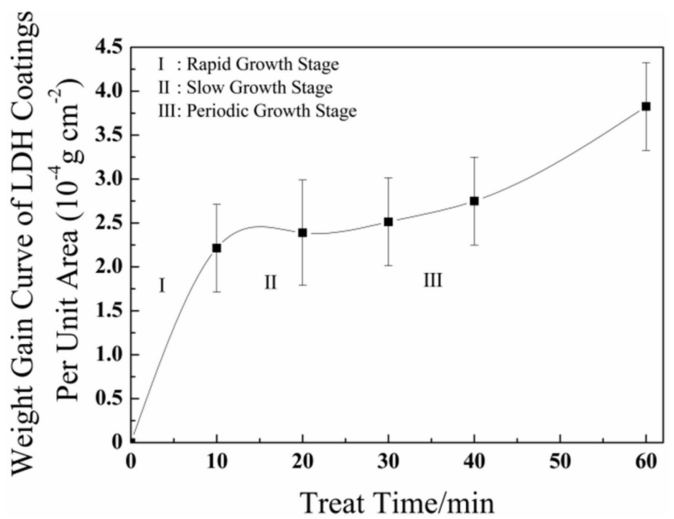

Figure 5. Weighted gain curves of the LDHs coatings at different formation times. 


\subsection{Apparent Activation Energy}

Since the initial LDHs coating is mainly composed of $\mathrm{Mg}$ and $\mathrm{Al}$ hydroxide precipitation, the growth rate of the LDHs coating is determined by the reduction-reaction rate of $\mathrm{OH}^{-}$in the micro-cathode region. The apparent activation energy $E_{\mathrm{a}}$ can be regarded as a constant in a certain range, since the formation reaction temperature is set. The increasing mass of the processing time per unit and the formation temperature will meet the equation as follows [52]:

$$
\ln \frac{v_{2}}{v_{1}}=\frac{E_{\mathrm{a}}}{R}\left(\frac{1}{T_{1}}-\frac{1}{T_{2}}\right)
$$

In Equation (1), $v$ denotes the increasing mass of the coating per unit processing time ( $\left.\mathrm{mg} \mathrm{min}^{-1}\right)$. $R$ is constantly set as $8.3143 \mathrm{~J} \mathrm{~mol}^{-1} \mathrm{~K}^{-1}$.

The apparent activation energy of the LDHs coatings was calculated in three growth stages, with a measurement of their increasing mass being taken at 30 and $50{ }^{\circ} \mathrm{C}$ for 10,20 and $30 \mathrm{~min}$, respectively, as shown in Table 1.

Table 1. Apparent activation energy at the three growth stages of the LDH coatings.

\begin{tabular}{ccccccc}
\hline Condition & \multicolumn{2}{c}{$\mathbf{1 0} \mathbf{~} \mathbf{m i n}, \mathbf{5 0}{ }^{\circ} \mathbf{C}$} & \multicolumn{2}{c}{$\mathbf{2 0} \mathbf{~} \mathbf{m i n}, \mathbf{5 0}{ }^{\circ} \mathbf{C}$} & \multicolumn{2}{c}{$\mathbf{3 0} \mathbf{~ m i n}, \mathbf{5 0}{ }^{\circ} \mathbf{C}$} \\
\hline$\Delta m(\mathrm{mg})$ & 1.39 & 1.81 & 1.41 & 2.06 & 1.41 & 2.17 \\
\hline$E_{\mathrm{a}}\left(\mathrm{KJ} \mathrm{mol}^{-1}\right)$ & \multicolumn{2}{c}{21.78} & \multicolumn{2}{c}{31.86} & \multicolumn{2}{c}{34.92} \\
\hline
\end{tabular}

\subsection{Effect of $\mathrm{CO}_{2}$ Solubility}

$\mathrm{CO}_{2}$ solubility directly determines the formation effect of the LDHs coating, due to the formation solution itself being a carbonate/bicarbonate ions solution. Essentially, the solubility of gas-solutes is a matter of vapor-liquid equilibrium. According to the Second Law of Thermodynamics, if all spontaneous processes occur in an isothermal-isobaric closed system, the Free Gibb's Energy of the system will decrease until the equilibrium state where the Free Gibb's Energy of the system has reached the minimum. Therefore, if an isothermal-isobaric closed system achieves equilibrium, it can be considered that:

$$
(\mathrm{dG})_{T, P}=0
$$

Equation (2) denotes the gas as gradually dissolving in the liquid, finally reaching a state of saturation. A gas-liquid equilibrium is then formed. Therefore, gas solubility can be defined as the solute concentration in a liquid solvent at gas-liquid equilibrium. In this formation system, the pressure and temperature directly affects the solubility of $\mathrm{CO}_{2}$. The solute density is usually described by the equation of the state. According to the BWRS equation, [51] the equation is as follows:

$$
\begin{array}{r}
p=\rho R T+\left[B_{0} R T-A_{0}-\frac{C_{0}}{T^{2}}+\frac{D_{0}}{T^{3}}-\frac{E_{0}}{T^{4}}\right] \rho^{2}+\left[b R T-a-\frac{d}{T}\right] \rho^{3}+\alpha\left[a+\frac{d}{T}\right] \rho^{6}+ \\
\frac{c \rho^{3}}{T^{2}}\left[1+\gamma \rho^{2}\right] \exp \left[-\gamma \rho^{2}\right]
\end{array}
$$


In Equation (3), $P$ is the pressure of the system, $\mathrm{kPa}$; $T$ is temperature of the system, $\mathrm{K} ; \rho$ is the gas or liquid density, $\mathrm{kmol} \mathrm{m}^{-3}$; and $R$ is the gas constant, $R=8.3143 \mathrm{KJ} \mathrm{kmol}^{-1} \mathrm{~K}^{-1}$ ).

$$
\left\{\begin{array}{l}
\rho_{c i} B_{0 i}=A_{1}+B_{1} \omega_{i} ; \rho_{c i}^{3}=A_{7}+B_{7} \omega_{i} \\
\frac{\rho_{e i} A_{0 i}}{R T_{c i}}=A_{2}+B_{2} \omega_{i} ; \frac{\rho_{c i}^{2} c_{i}}{R T_{c i}^{3}}=A_{8}+B_{8} \omega_{i} \\
\frac{\rho_{e i} A_{0 i}}{R T_{c i}^{3}}=A_{3}+B_{3} \omega_{i} ; \frac{\rho_{c i}^{2 i} d_{i}}{R T_{c i}^{2}}=A_{10}+B_{10} \omega_{i} \\
\rho_{c i}^{2} \gamma_{i}=A_{4}+B_{4} \omega_{i} ; \frac{\rho_{c i}^{2} D_{0 i}}{R T_{c i}^{i}}=A_{9}+B_{9} \omega_{i} \\
\rho_{c i}^{2} b_{i}=A_{5}+B_{5} \omega_{i} ; \frac{\rho_{c i}^{2} E_{0 i}}{R T_{c i}^{5}}=A_{11}+B_{11} \omega_{i} e^{-3.8 \omega_{i}} \\
\frac{\rho_{c i}^{2} a_{i}}{R T_{c i}}=A_{6}+B_{6} \omega_{i}
\end{array}\right\}
$$

In Equation (4), $A_{0}, B_{0}, C_{0}, D_{0}, E_{0}, a, b, c, d, \alpha$, and $\gamma$ are the 11 parameters of the state equation. Each parameter of the pure component $i$ can be calculated from its critical parameter, critical density, and eccentricity factor by Equation (4). In this equation, the universal constant $(i=1,2,3, \ldots, 11)$ is shown in Table 2.

Table 2. The values of the general constants.

\begin{tabular}{ccc}
\hline $\boldsymbol{i}$ & $\boldsymbol{A}_{\boldsymbol{i}}$ & $\boldsymbol{B}_{\boldsymbol{i}}$ \\
\hline 1 & 0.443 & 0.115 \\
2 & 1.284 & -0.921 \\
3 & 0.356 & 1.708 \\
4 & 0.545 & -0.171 \\
5 & 0.528 & 0.349 \\
6 & 0.484 & 0.754 \\
7 & 0.071 & -0.044 \\
8 & 0.504 & 1.322 \\
9 & 0.031 & 0.179 \\
10 & 0.073 & 0.463 \\
11 & 0.006 & -0.022 \\
\hline
\end{tabular}

The solubility of $\mathrm{CO}_{2}$ was calculated by Equations (3) and (4) in $\mathrm{CO}_{2}$ pressurization, and is shown in Figure 6, where the solubility of $\mathrm{CO}_{2}$ increases along with the increase in pressure. $\mathrm{CO}_{2}$ pressurization directly affects the solubility of $\mathrm{CO}_{2}$, determining the concentration of $\mathrm{CO}_{3}{ }^{2-} / \mathrm{HCO}_{3}{ }^{-}$ ions, as well as the $\mathrm{pH}$ of the formation solution. The change in the concentration of the $\mathrm{HCO}_{3}{ }^{-} / \mathrm{CO}_{3}{ }^{2-}$ ions was calculated by the ionization equation during the formation process, as shown in Figure 7 . Corresponding to this, the $\mathrm{pH}$ was also calculated, as shown in Figure 8.

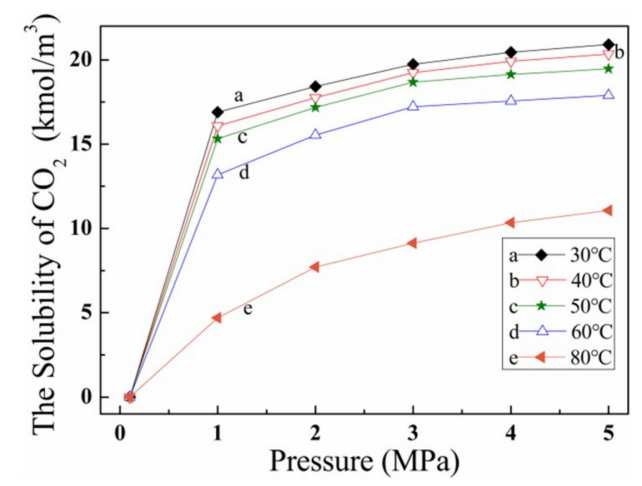

Figure 6. The solubility of $\mathrm{CO}_{2}$ for a $\mathrm{CO}_{2}-\mathrm{H}_{2} \mathrm{O}$ system at different temperatures and pressures. 


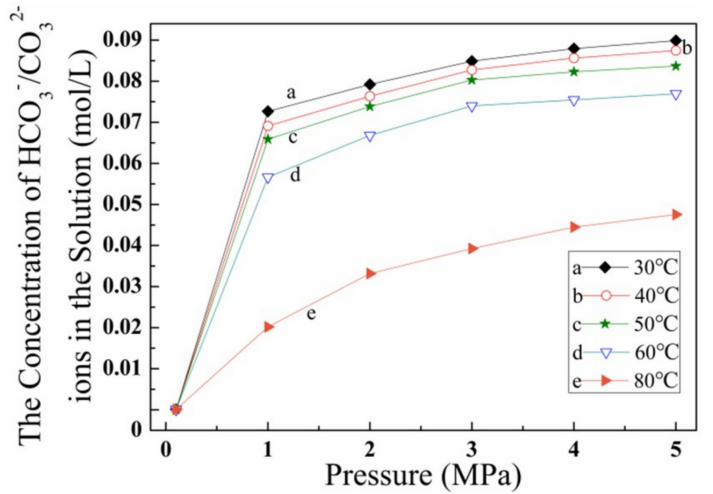

Figure 7. Concentration of the $\mathrm{HCO}_{3}{ }^{-} / \mathrm{CO}_{3}{ }^{2-}$ ions in the formation solution at different temperatures and pressures.

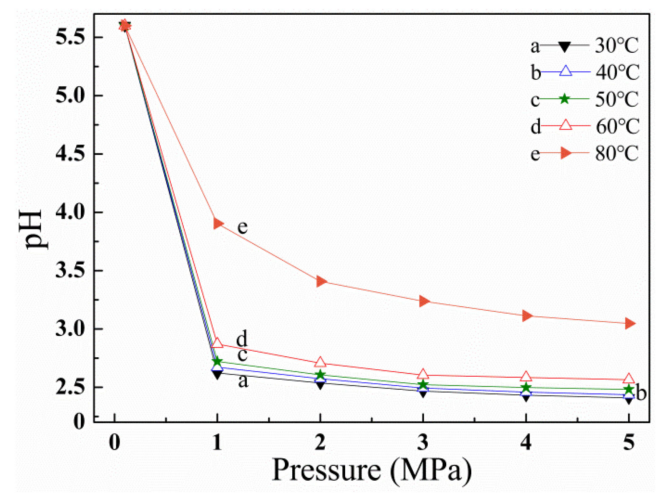

Figure 8. The $\mathrm{pH}$ curves of the formation solution at different temperatures and pressures.

\subsection{Anti-Corrosion Properties}

The potentiodynamic polarization curves in the $3.5 \% \mathrm{NaCl}$ solution of the LDHs coatings were tested by the three-electrode system, and these are shown in Figure 9. Using the Butler-Volmer equation, the corrosion potential $E_{\text {corr }}$ and the corrosion current $i_{\text {corr }}$ were determined based on the Tafel extrapolation method. The results are shown in Table 3. The hydrogen evolution data (HER) of the LDHs coatings at different formation times in $3.5 \% \mathrm{NaCl}$ solution are shown in Figure 10. The immersion test results of $120 \mathrm{~h}$ were employed to evaluate the corrosion resistance of the LDHs coatings, and these are shown in Figure 11.

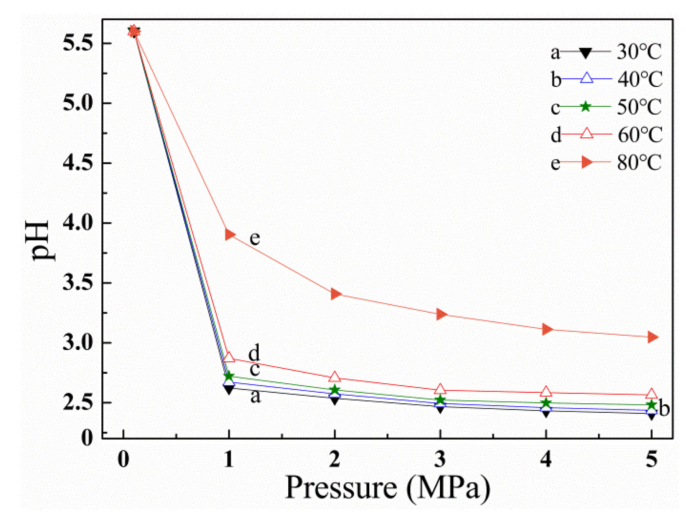

Figure 9. Polarization curves of the LDHs coatings at different formation times in $3.5 \% \mathrm{NaCl}$ solution. 
Table 3. Electrochemical parameters of the LDHs conversion coatings at different times.

\begin{tabular}{cccc}
\hline Sample & $\boldsymbol{E}_{\text {corr }}(\mathbf{V}$ vs. SCE) & $\boldsymbol{I}_{\text {corr }}\left(\boldsymbol{\mu} \mathbf{A ~ c m} \mathbf{~ c m}^{-2}\right)$ & Efficiency $\%$ \\
\hline AZ91D & $-1.41(0.059)$ & $83.62(1.67)$ & - \\
$10 \mathrm{~min}$ & $-1.39(0.047)$ & $30.11(1.69)$ & $63.99 \%$ \\
$20 \mathrm{~min}$ & $-1.37(0.031)$ & $10.53(1.63)$ & $87.41 \%$ \\
$30 \mathrm{~min}$ & $-1.36(0.034)$ & $8.92(1.63)$ & $89.33 \%$ \\
$40 \mathrm{~min}$ & $1.38(0.042)$ & $20.19(1.73)$ & $75.86 \%$ \\
$1 \mathrm{~h}$ & $-1.39(0.47)$ & $28.73(1.62)$ & $65.64 \%$ \\
\hline
\end{tabular}

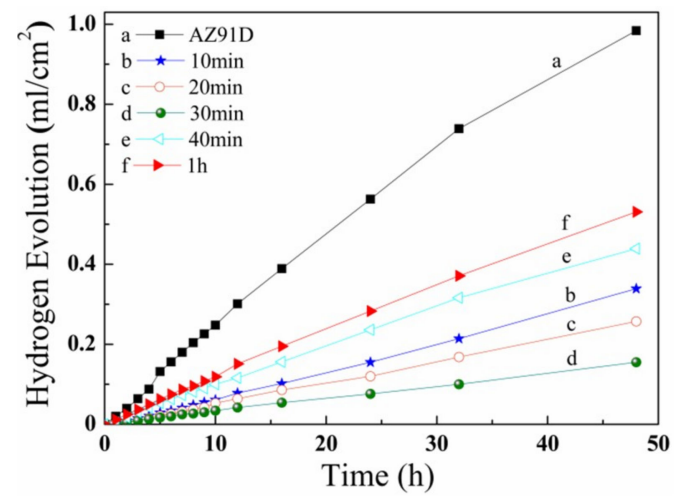

Figure 10. Hydrogen evolution curves of the LDHs coatings at different formation times in $3.5 \%$ $\mathrm{NaCl}$ solution.

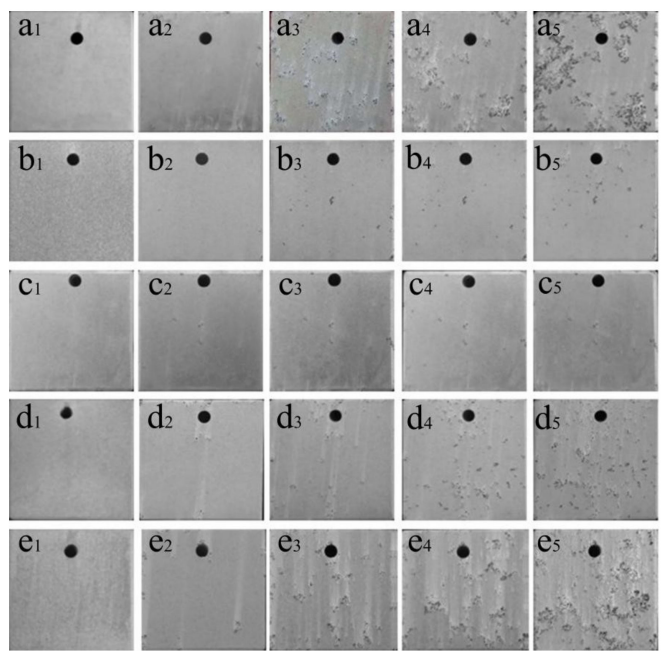

Figure 11. Optical corrosion morphologies of the LDHs coatings at different formation times after $120 \mathrm{~h}$ of immersion testing in $3.5 \% \mathrm{NaCl}$ solution: $\left(\mathbf{a}_{1}\right) 10$ min sample immersed for $0 \mathrm{~h} ;\left(\mathbf{a}_{2}\right) 10 \mathrm{~min}$ sample immersed for $24 \mathrm{~h} ;\left(\mathbf{a}_{3}\right) 10$ min sample immersed for $48 \mathrm{~h} ;\left(\mathbf{a}_{\mathbf{4}}\right) 10 \mathrm{~min}$ sample immersed for 72

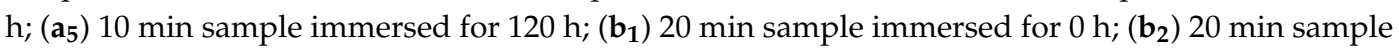

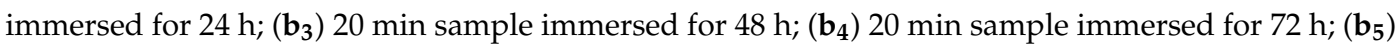
20 min sample immersed for $120 \mathrm{~h} ;\left(\mathbf{c}_{\mathbf{1}}\right) 30 \mathrm{~min}$ sample immersed for $\left.0 \mathrm{~h} ; \mathbf{c}_{\mathbf{2}}\right) 30 \mathrm{~min}$ sample immersed

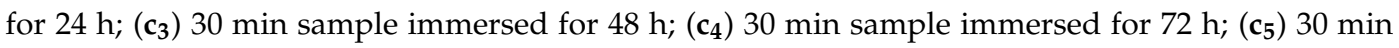

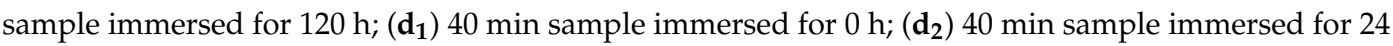
h; $\left(\mathbf{d}_{3}\right) 40$ min sample immersed for $48 \mathrm{~h} ;\left(\mathbf{d}_{\mathbf{4}}\right) 40$ min sample immersed for $72 \mathrm{~h} ;\left(\mathbf{d}_{5}\right) 40$ min sample

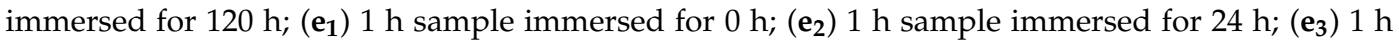
sample immersed for $48 \mathrm{~h} ;\left(\mathbf{e}_{4}\right) 1 \mathrm{~h}$ sample immersed for $72 \mathrm{~h} ;\left(\mathbf{e}_{5}\right) 1 \mathrm{~h}$ sample immersed for $120 \mathrm{~h}$. 


\section{Discussion}

\subsection{Influence of the Micro-Structure on the Formation Process}

The LDHs coatings were formed layer-by-layer from the micro-structural results. The initially formed positions were on the $\alpha-\mathrm{Mg}$ phase, and subsequently, on the $\beta-\mathrm{Mg}_{17} \mathrm{Al}_{12}$ phase. The possible reason could be the potential differences between $\alpha-\mathrm{Mg}$ and $\beta-\mathrm{Mg}_{17} \mathrm{Al}_{12}$. The $\beta-\mathrm{Mg}_{17} \mathrm{Al}_{12}$ phase became the cathode phase, thereby facilitating the dissolution of the $\alpha-\mathrm{Mg}$ phase [49]. The coating was found to be the most even and compact after $30 \mathrm{~min}$. The coating continued to grow between $40 \mathrm{~min}$ to $1 \mathrm{~h}$, with severe cracks and holes appearing after $1 \mathrm{~h}$. The results of the GAXRD patterns in Figure 4 are consistent with Figure 3.

\subsection{Influence of Physical and Chemical Processes on the Formation Process}

In essence, the formation process of the LDHs coating is a kind of physical and chemical process. The reaction process mainly includes an electrochemical reaction, an ionization reaction, and a formation reaction. The specific chemical reactions of formation within the LDHs coating are shown in Equations (5)-(11) [53-56].

$$
\begin{gathered}
\mathrm{CO}_{2}+\mathrm{H}_{2} \mathrm{O} \rightarrow \mathrm{H}_{2} \mathrm{CO}_{3} \\
\mathrm{Mg}-2 \mathrm{e}^{-} \rightarrow \mathrm{Mg}^{2+} \\
\mathrm{Al}-3 \mathrm{e}^{-} \rightarrow \mathrm{Al}^{3+} \\
2 \mathrm{H}^{+}+2 \mathrm{e}^{-} \rightarrow \mathrm{H}_{2}(\mathrm{~g}) / \mathrm{H}_{2} \mathrm{O}+2 \mathrm{e}^{-} \rightarrow \mathrm{H}_{2}(\mathrm{~g})+2 \mathrm{OH}^{-} \\
\mathrm{H}_{2} \mathrm{CO}_{3} \rightarrow \mathrm{HCO}_{3}{ }^{-}+\mathrm{H}^{+} \\
\mathrm{H}_{2} \mathrm{CO}_{3} \rightarrow \mathrm{CO}_{3}{ }^{2-}+2 \mathrm{H}^{+} \\
6 \mathrm{Mg}^{2+}+2 \mathrm{Al}^{3+}+\mathrm{CO}_{3}{ }^{2-}+16 \mathrm{OH}^{-}+4 \mathrm{H}_{2} \mathrm{O} \rightarrow \mathrm{Mg}_{6} \mathrm{Al}_{2}(\mathrm{OH})_{16} \mathrm{CO}_{3} \cdot 4 \mathrm{H}_{2} \mathrm{O}
\end{gathered}
$$

The weighted gain curve and apparent activation energy shows that the formation process of the LDHs coatings can be divided into three stages, with the apparent activation energies being different at each of the three stages. The reason is the physical and chemical processes on the surface of the magnesium alloy are also different at each of these three stages. During the rapid growth stage (0-10 $\mathrm{min})$, the existing uneven electrochemical regions were a result of the grain boundaries and dislocations on the surface of the magnesium alloy, with the higher energies of these regions easily forming many micro-batteries. Therefore, it was easy for coatings to grow and diffuse around these places [53]. Meanwhile, a large amount of $\mathrm{OH}^{-}$is produced in the micro-cathode region, reaching the $\mathrm{pH}$ value required for the formation of LDHs, and resulting in the rapid formation of coatings (see Equation (11)). During the slow growth stage (10-20 min), the LDHs coatings appear to be stable, with the diffusion and migration of the electrons and $\mathrm{O}_{2}$ being affected by the formation of the LDHs coatings on the metal surface, thereby inhibiting the oxygen reduction reaction in the micro-cathode region, and resulting in the slow growth of the LDH coatings. During the periodic growth stage (30-60 $\mathrm{min})$, the formation and dissolution reactions of the LDHs coatings tend to be balanced in a periodic state.

From the calculated values of the activation energy in the three stages, it can be seen that the activation energy was only $21.78 \mathrm{~kJ} \mathrm{~mol}^{-1}$ during the first stage. Thus, the formation rate is faster and it is seen as the rapid formation stage. A large amount of $\mathrm{OH}^{-1}$ is generated in the micro-cathode region, helping to facilitate the reduction reaction. In the second stage, the activation energy of the formation reaction was increased to $31.86 \mathrm{~kJ} \mathrm{~mol}^{-1}$, with the formation rate gradually slowing down. The reduction reaction in the micro-cathode region was weakened, due to the formation of the LDHs coating from the previous stage, which took $30 \mathrm{~min}$ to complete a growth cycle. The activation energy in the third stage was $34.92 \mathrm{~kJ} \mathrm{~mol}^{-1}$, which was kept constantly within a certain range of $\mathrm{kJ} \mathrm{mol}^{-1}$. 
The formation reaction appeared to have greater difficulties than the first two stages, which were consistent with the results of the above analysis.

\subsection{Influence of $\mathrm{CO}_{2}$ Pressurization on the Formation Process}

The solubility of $\mathrm{CO}_{2}$ in water was increased concurrently with the pressure (Figure 6), leading to a series of changes in the physical and chemical processes. According to Le Chatelier's principle, it led to the electrochemical reaction (Equation (5)) and the ionization reaction (Equations (9) and (10)) to the right, along with an increase in the concentration of hydrogen ions in the formation solution. The electrochemical reaction (Equations (6)-(8)) was promoted to the right. This is consistent with the change tendency of the $\mathrm{HCO}_{3}{ }^{-} / \mathrm{CO}_{3}{ }^{2-}$ ion concentration calculated in Figure 7. The $\mathrm{pH}$ of the formation solution (Figure 8) decreased with the pressure, which also led to the electrochemical reactions (Equations (6)-(8)) to the right, and an acceleration in the dissolution of aluminum and magnesium ions. The acceleration of electrochemical and ionizational reactions promoted the formation reaction of the LDHs coatings (Equation (11)) on the magnesium alloy surface, with an increase in magnesium, aluminum, carbonate, and hydroxyl ions. The pressure of the formation system remained at a stable value, ensuring the stability of the formation system, and thus, implementing the stability of the formation process.

\subsection{Influence of the Formation Time on the Anti-Corrosion Properties}

The electrochemical test results showed that the anodic reaction of the LDHs coating was significantly inhibited (Figure 9). The $i_{\text {corr }}$ can be ranked by the series: $30 \mathrm{~min}<20 \mathrm{~min}<40 \mathrm{~min}<1 \mathrm{~h}$ $<10 \mathrm{~min}<\mathrm{AZ91D}$. The $i_{\text {corr }}\left(8.92 \mu \mathrm{A} \mathrm{cm}{ }^{-2}\right)$ of the LDHs coating was lowest at $30 \mathrm{~min}$. Meanwhile, the efficiency percentage (efficiency \%) of the LDHs coating was highest in the same condition. The hydrogen evolution reaction at the cathode is the main reason for the corrosion of the magnesium alloys. Thus, the hydrogen evolution rate is proportional to the corrosion rate [57-61]. The hydrogen evolution process also shows the same result as the aforementioned reaction (Figure 10). The hydrogen evolution performance of the $30 \mathrm{~min}$ coating at $50{ }^{\circ} \mathrm{C}$ was $0.155 \mathrm{~mL} \mathrm{~cm}^{-2}$, due to the coating formation at $30 \mathrm{~min}$ being denser than those processed at other processing times.

The samples processed for $10 \mathrm{~min}$ and $1 \mathrm{~h}$ underwent severe corrosion, with a corrosion damage level of 3G. The level of the corrosion damage of samples processed for 20,30 and 40 min were less severe, especially the sample processed for $30 \mathrm{~min}$ (Figure 11). The sample surface of the samples processed for 30 min essentially remained intact after immersion for $120 \mathrm{~h}$, with only slight corrosion appearing during this time. The level of corrosion damage was evaluated as $7 \mathrm{G}, 7 \mathrm{G}$, and $6 \mathrm{G}$ for samples processed for 20, 30 and $40 \mathrm{~min}$, respectively. The results of the polarization curves, HER curves, and immersion tests consistently showed that AZ91D alloy had better anti-corrosion properties after 30 min of the $\mathrm{CO}_{2}$ pressurization method. In sum, the anti-corrosive performance of the LDHs coatings can be ranked in the increasing series: AZ91D $<10 \mathrm{~min}<1 \mathrm{~h}<40 \mathrm{~min}<20 \mathrm{~min}<30 \mathrm{~min}$.

\subsection{Comparison with the State-of-the-Art Technology}

To further prove the formation effect of the $\mathrm{CO}_{2}$ pressurization method, comparisons were made between the $\mathrm{CO}_{2 \_} 3 \mathrm{MPa} \_0.5 \mathrm{~h}$ (30 min treatment sample) treatment and the currently mature preparation methods. The first comparison is the one step method, the samples were statically immersed in a bath at $50{ }^{\circ} \mathrm{C}$ for a particular period for $24 \mathrm{~h}$, and it was denoted above as the $\mathrm{CO}_{2} 24 \mathrm{~h}$ treatment [37]. The two-step method was then performed: the samples were placed in the solution through which $\mathrm{CO}_{2}$ gas was continuously bubbled for $2 \mathrm{~h}$. This treatment is called the $\mathrm{CO}_{2} 2 \mathrm{~h}$ treatment. A separate $\mathrm{HCO}_{3}{ }^{-} / \mathrm{CO}_{3}{ }^{2-}$ solution were maintained at $\mathrm{pH} 11.5$ by the dropwise addition of $1.25 \mathrm{M}$ aqueous $\mathrm{NaOH}$ with vigorous stirring. The $\mathrm{CO}_{2} \_2 \mathrm{~h}$ treatment was immediately hydrothermally treated by dipping in a $\mathrm{pH} 11.5 \mathrm{HCO}_{3}{ }^{-} / \mathrm{CO}_{3}{ }^{2-}$ solution at $50{ }^{\circ} \mathrm{C}$ for $2 \mathrm{~h}$. This was denoted by $\mathrm{CO}_{2} 2$ $\mathrm{h} / \mathrm{pH} 11.5 \_2 \mathrm{~h}[41]$. For the perspective of the formation technology, the preparation efficiency of the $\mathrm{CO}_{2} \_3 \mathrm{MPa} \_0.5 \mathrm{~h}$ treatment was eight and 48 times higher than the $\mathrm{CO}_{2 \_} 2 \mathrm{~h} / \mathrm{pH} 11.5 \_2 \mathrm{~h}$ and $\mathrm{CO}_{2 \_} \_4$ 
$\mathrm{h}$ treatments. For the perspective of anti-corrosion performance, the sample of the $\mathrm{CO}_{2} \_24 \mathrm{~h}$ treatment and the $\mathrm{CO}_{2} \_2 \mathrm{~h} / \mathrm{pH} 11.5 \_2 \mathrm{~h}$ treatments showed multiple areas of corrosion, and the sample of $\mathrm{CO}_{2} \_3$ $\mathrm{MPa} \_.5 \mathrm{~h}$ treatment was basically intact, after immersion for $48 \mathrm{~h}$ in $3.5 \% \mathrm{NaCl}$ solution, as shown in Figure 12. The $\mathrm{CO}_{2} \_3 \mathrm{MPa} \_0.5 \mathrm{~h}$ treatment is observably better than the $\mathrm{CO}_{2} \_24 \mathrm{~h}$ and $\mathrm{CO}_{2} \_2 \mathrm{~h} / \mathrm{pH}$ $11.5 \_2 \mathrm{~h}$.

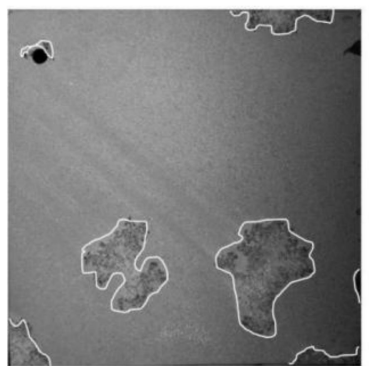

(a)

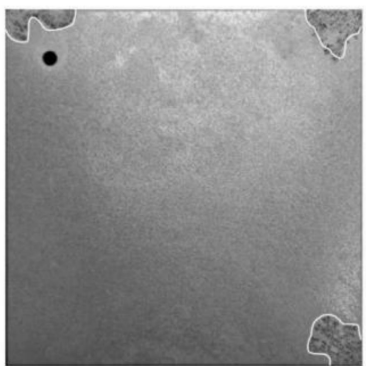

(b)

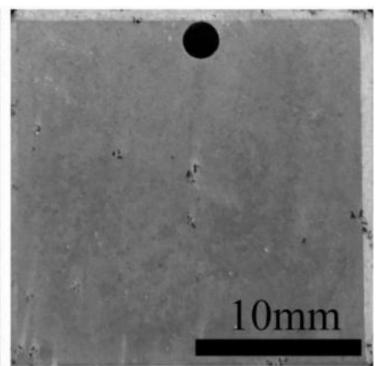

(c)

Figure 12. The result of the comparison with the state-of-the-art technology of the immersion test in 3.5\% $\mathrm{NaCl}$ solution: (a) $\mathrm{CO}_{2} \_24 \mathrm{~h}$ sample immersed for $48 \mathrm{~h}$, (b) $\mathrm{CO}_{2} \_\mathrm{h} / \mathrm{pH} 11.5 \_2 \mathrm{~h}$ sample immersed for $48 \mathrm{~h}$, (c) $\mathrm{CO}_{2} \_3 \mathrm{MPa} 0.5 \mathrm{~h}$ sample immersed for $48 \mathrm{~h}$.

\section{Conclusions}

- The initial formation position in the formation process of the LDHs coating on magnesium alloy is on the $\alpha-\mathrm{Mg}$ phase, and subsequently on the $\beta-\mathrm{Mg}_{17} \mathrm{Al}_{12}$ phase. The most even and dense coating was found after $30 \mathrm{~min}$, where the LDHs coating appeared to severe cracks and holes, and especially so after $1 \mathrm{~h}$.

- The formation process of the LDHs coating can be divided into three stages: a rapid growth stage, a slow growth stage, and a periodic growth stage. During the rapid growth stage (0-10 min), the weight of the LDHs coatings increasing rapidly, with a minimum value of activation energy $\left(21.78 \mathrm{~kJ} \mathrm{~mol}^{-1}\right)$. During the slow growth stage (10-20 $\left.\mathrm{min}\right)$, the weight of the LDHs coatings grew stably, with a growing value of activation energy $\left(31.86 \mathrm{~kJ} \mathrm{~mol}^{-1}\right)$. Finally, during the periodic growth period, the formation and dissolution of the LDHs coatings tended to be balanced, with a maximum value of activation energy $\left(34.92 \mathrm{~kJ} \mathrm{~mol}^{-1}\right)$.

- $\mathrm{CO}_{2}$ pressurization promotes the shifts of the ionization reaction and the electrochemical reaction to the right, thereby accelerating the formation reaction, which increases the formation reaction rate and formation stability.

- The anti-corrosion of the LDHs coating is gradually improved with the increase in formation time. The $i_{\text {corr }}$ (corrosion current) of the LDHs coating was minimal at $30 \mathrm{~min}$, and had a higher efficiency percentage. The LDHs coating has a compact micro-structure, and better anti-corrosion at a pressure of $3 \mathrm{MPa}$, a temperature of $50{ }^{\circ} \mathrm{C}$, and a time of $30 \mathrm{~min}$. Comparing with the state-of-the-art technology, the $\mathrm{CO}_{2} \_3 \mathrm{MPa} \_0.5 \mathrm{~h}$ treatment is observably better than $\mathrm{CO}_{2} \_24 \mathrm{~h}$ and $\mathrm{CO}_{2} \_2 \mathrm{~h} / \mathrm{pH} 11.5 \_2 \mathrm{~h}$ treatments.

Author Contributions: Conceptualization, X.Z. and T.Z.; Methodology, X.Z., J.W. and C.Z.; Software, X.Z., J.W. and C.Z.; Validation, X.Z., T.Z., G.M. and F.W.; Formal Analysis, X.Z., B.L. and T.Z.; Investigation, X.Z., C.Z., B.L., P.J. and T.Z.; Resources, X.W., B.L., B.B., T.Z. and G.M.; Data Curation, X.Z., B.L., T.Z., G.M. and F.W.; Writing-Original Draft Preparation, X.Z., J.W., C.Z., B.L., Y.Z. and C.Z.; Writing-Review \& Editing, X.Z., Y.Z., P.J. and T.Z.; Visualization, X.Z., C.Z., P.J. and Y.Z; Supervision, B.B., B.L., T.Z., G.M. and F.W.; Project Administration, X.Z., B.L., T.Z. and F.W.; Funding Acquisition, X.C., B.L., T.Z. and F.W.

Funding: The research was funded by the National Program for the Young Top-notch Professionals, the National Natural Science Foundation of China (No. 51531007, 51771050, 51705038), and Foundation of Young Scholars in HLJIT (No. 2014QJ12).

Conflicts of Interest: The authors declare no conflict of interest. 


\section{References}

1. Chen, X.H.; Geng, Y.X.; Pan, F.S. Research Progress in Magnesium Alloys as Functional Materials. Rare Met. Mater. Eng. 2016, 45, 2269-2274. [CrossRef]

2. Song, G.; Xu, Z. The surface, microstructure and corrosion of magnesium alloy AZ31 sheet. Electrochim. Acta 2010, 55, 4148-4161. [CrossRef]

3. Shi, F.; Wang, C.Q.; Zhang, Z.M. Microstructures, corrosion and mechanical properties of as-cast MgZnY(Gd) alloys. Trans. Nonferrous Met. Soc. China 2015, 25, 2172-2180. [CrossRef]

4. Atrens, A.; Song, G.L.; Liu, M. Review of recent devel-opments in the field of magnesium corrosion. Adv. Eng. Mater. 2015, 17, 400-453. [CrossRef]

5. Cao, F.; Song, G.L.; Atrens, A. Corrosion and passivation of magnesium alloys. Corros. Sci. 2016, 111, 835-845. [CrossRef]

6. Brown, R. International Mg Association 55th Annual World Conference. Light Met. Age. 1998, 56, 86-93.

7. Eliezer, D.; Aghion, E.; Fores, F.H. Magnesium science, technology and applications. Adv. Perform. Mater. 1998, 5, 201-212. [CrossRef]

8. Toshihide, T.; Yuji, N.; Nobuo, U.; Masahiro, K. Improvement of corrosion resistance of magnesium metal by rare earth elements. Electrochim. Acta 2007, 1, 117-121. [CrossRef]

9. Song, Y.L.; Liu, Y.H.; Wang, S.H. Effect of cerium addition on microstructure and corrosion resistance of die cast AZ91 magnesium alloy. Mater. Corros. 2007, 3, 189-192. [CrossRef]

10. Tong, G.D.; Liu, H.F.; Liu, Y.H. Effec of rare earth additions on microstructure and mechanical properties of AZ91 magnesium alloys. Trans. Nonferrous Met. Soc. China 2010, 20, 336-340. [CrossRef]

11. Zhang, J.; Xu, M.; Teng, X.; Zuo, M. Effect of Gd addition on microstructure and corrosion behaviors of Mg-Zn-Y alloy. J. Magn. Alloy 2016, 4, 319-325. [CrossRef]

12. Zhou, H.; Xu, W.Z.; Jian, W.W. A new metastable precipitate phase in Mg-Gd-Y-Zr alloy. Philos. Mag. 2014, 21, 2403-2409. [CrossRef]

13. Zhou, H.; Wang, Q.D.; Guo, W.; Ye, B.; Jian, W.W.; Xu, W.Z.; Ma, X.L.; Moering, J. Finite element simulation and experimental investigation on homogeneity of Mg-9.8Gd-2.7Y-0.4Zr magnesium alloy processed by repeated-up setting. J. Mater. Process. Technol. 2015, 225, 310-317. [CrossRef]

14. Zhou, H.; Cheng, G.M.; Ma, X.L.; Xu, W.Z.; Mathaudhu, S.N.; Wang, Q.D.; Zhu, Y.T. Effect of Ag on interfacial segregation in Mg-Gd-Y-(Ag)-Zr alloy. Acta Mater. 2015, 95, 20-29. [CrossRef]

15. Liang, C.H.; Wang, S.S.; Huang, N.B. Effects of Lanthanum and Cerium Mixed Rare Earth Metal on Abrasion and Corrosion Resistance of AM60 Magnesium Alloy. Rare Metal Mater. Eng. 2015, 3, 521-526. [CrossRef]

16. Zhou, H.; Ning, H.Y.; Ma, X.L. Microstructural evolution and mechanical properties of Mg-9.8Gd-2.7Y-0.4Zr alloy produced by repetitive upsetting. J. Mater. Sci. Technol. 2018, 34, 1067-1075. [CrossRef]

17. Emley, E.F. Principles of Magnesium Technology; Pegamon Press: New York, NY, USA, 1966.

18. Zhang, Y.; Yan, C.; Wang, F. Study on the environmentally friendly anodizing of AZ91D magnesium alloy. Surf. Coat. Technol. 2002, 1, 36-43. [CrossRef]

19. Song, G.L. Recent progress in corrosion and protection of magnesium alloys. Adv. Eng. Mater. 2005, 7, 563-586. [CrossRef]

20. Pommiers, S.; Frayret, J.; Castetbon, A. Alternative conversion coatings to chromate for the protection of magnesium alloys. Corros. Sci. 2014, 84, 135-146. [CrossRef]

21. Jiang, X.; Guo, R.G.; Jiang, S.Q. Microstructure and corrosion resistance of Ce-V conversion coatingon AZ31 magnesium alloy. Appl. Surf. Sci. 2015, 341, 166-174. [CrossRef]

22. Zeng, R.C.; Hu, Y.; Zhang, F. Corrosion resistance of cerium-doped zinc calcium phosphate chemical conversion coatings on AZ31 magnesium alloy. Trans. Nonferrous Met. Soc. 2016, 26, 472-483. [CrossRef]

23. Chen, X.B.; Yang, H.Y.; Abbott, T.B. Corrosion protection of magnesium and itsalloys by metal phosphate conversion coatings. Surf. Eng. 2014, 30, 871-879. [CrossRef]

24. Phuong, N.V.; Gupta, M.; Moon, S. Enhanced corrosion performance of magnesium phosphate conversion coating on AZ31 magnesium alloy. Trans. Nonferrous Met. Soc. 2017, 27, 1087-1095. [CrossRef]

25. Jian, S.Y.; Chu, Y.R.; Lin, C.S. Permanganate conversion coating on AZ31 magnesium alloys with enhanced corrosion resistance. Corros. Sci. 2015, 93, 301-309. [CrossRef] 
26. Lee, Y.L.; Chu, Y.R.; Li, W.C. Effect of permanganate concentration on the formation and properties of phosphate/permanganate conversion coating on AZ31 magnesium alloy. Corros. Sci. 2013, 70, 74-81. [CrossRef]

27. Mosiałek, M.; Mordarski, G.; Nowak, P. Phosphate-permanganate conversion coatings on the AZ81 magnesium alloy; SEM, EIS and XPS studies. Surf. Coat. Technol. 2011, 206, 51-62. [CrossRef]

28. Yang, L.H.; Zhang, M.L.; Li, J.Q. Stannate conversion coatings on Mg-8Li alloy. J. Alloys Compd. 2009, 471, 97-200. [CrossRef]

29. Lee, Y.L.; Chu, Y.R.; Chen, F.J. Mechanism of the formation of stannate and cerium conversion coatings on AZ91D magnesium alloys. Appl. Surf. Sci. 2013, 276, 578-585. [CrossRef]

30. Ma, Y.B.; Li, N.; Li, D.Y.; Huang, X.M. Characteristics and corrosion studies of vanadate conversion coating formed on Mg-14 wt \% Li-1 wt \% Al-0.1 wt \% Ce alloy. Appl. Surf. Sci. 2012, 261, 59-67. [CrossRef]

31. Niu, L.Y.; Chang, S.H.; Tong, X. Analysis of characteristics of vanadate conversion coating on the surface of magnesium alloy. J. Alloy. Compd. 2014, 617, 214-218. [CrossRef]

32. Loperena, A.P.; Lehr, I.L.; Saidman, S.B. Formation of a cerium conversion coating on magnesium alloy using ascorbic acid as additive. Characterisation and anticorrosive properties of the formed film. J. Magn. Alloy 2016, 4, 278-285. [CrossRef]

33. Lei, L.; Shi, J.; Wang, X. Microstructure and electrochemical behavior of cerium conversion coating modified with silane agent on magnesium substrates. Appl. Surf. Sci. 2016, 376, 161-171. [CrossRef]

34. Kong, G.; Liu, L.Y.; Lu, J.T. Study on lanthanum salt conversion coating modified with citric acid on hot dip galvanized steel. J. Rare Earths 2010, 28, 461-465. [CrossRef]

35. Xu, S.; Liao, M.C.; Zeng, H.Y. Surface modification and dissolution behavior of $\mathrm{Mg}-\mathrm{Al}$ hydrotalcite particles. J. Taiwan. Inst. Chem. Eng. 2015, 56, 174-180. [CrossRef]

36. Wang, L.D.; Zhang, K.Y.; He, H.R. Enhanced corrosion resistance of MgAl hydrotalcite conversion coating on aluminum by chemical conversion treatment. Surf. Coat. Technol. 2013, 235, 484-488. [CrossRef]

37. Lin, J.K.; Hsia, C.L.; Uan, J.Y. Characterization of Mg, Al-hydrotalcite conversion film on $\mathrm{Mg}$ alloy and $\mathrm{Cl}^{-}$ and $\mathrm{CO}_{3}{ }^{2-}$ anion-exchangeability of the film in a corrosive environment. Scr. Mater. 2007, 56, 927-930. [CrossRef]

38. Lin, J.K.; Uan, J.Y. Formation of $\mathrm{Mg}$, Al-hydrotalcite conversion coating on $\mathrm{Mg}$ alloy in aqueous $\mathrm{HCO}_{3}{ }^{-} / \mathrm{CO}_{3}{ }^{2-}$ and corresponding protection against corrosion by the coating. Corros. Sci. 2009, 51, 1181-1188. [CrossRef]

39. Uan, J.Y.; Lin, J.K.; Sun, Y.S. Surface coatings for improving the corrosion resistance and cell adhesion of AZ91D magnesium alloy through environmentally clean methods. Thin Solid Films 2010, 518, 7563-7567. [CrossRef]

40. Uan, J.Y.; Lin, J.K.; Tung, Y.S. Direct growth of oriented $\mathrm{Mg}-\mathrm{Al}$ layered double hydroxide film on $\mathrm{Mg}$ alloy in aqueous $\mathrm{HCO}_{3}{ }^{-} / \mathrm{CO}_{3}{ }^{2-}$ solution. J. Mater. Chem. 2010, 20, 761-766. [CrossRef]

41. Lin, J.K.; Jeng, K.L.; Uan, J.Y. Crystallization of a chemical conversion layer that forms on AZ91D magnesium alloy in carbonic acid. Corros. Sci. 2011, 53, 3832-3839. [CrossRef]

42. Syu, J.H.; Uan, J.Y.; Lin, M.C. Optically transparent $\mathrm{Li}-\mathrm{Al}-\mathrm{CO}_{3}$ layered double hydroxide thin films on an AZ31 Mg alloy formed by electrochemical deposition and their corrosion resistance in a dilute chloride environment. Corros. Sci. 2013, 68, 238-248. [CrossRef]

43. Yu, B.L.; Lin, J.K.; Uan, J.Y. Applications of carbonic acid solution for developing conversion coating on $\mathrm{Mg}$ alloy. Trans. Nonferrous Met. Soc. China 2010, 20, 1331-1339. [CrossRef]

44. Chen, J.; Song, Y.W.; Shan, D.Y. In situ growth of Mg-Al hydrotalcite conversion film on AZ31 magnesium alloy. Corros. Sci. 2011, 53, 3281-3288. [CrossRef]

45. Chen, J.; Song, Y.W.; Shan, D.Y. Study of the corrosion mechanism of the in situ grown $\mathrm{Mg}-\mathrm{Al}-\mathrm{CO}_{3}{ }^{2-}$ hydrotalcite film on AZ31 alloy. Corros. Sci. 2012, 65, 268-277. [CrossRef]

46. Chen, J.; Song, Y.W.; Shan, D.Y. Modifications of the hydrotalcite film on AZ31 Mg alloy by phytic acid: The effects on morphology, composition and corrosion resistance. Corros. Sci. 2013, 74, 130-138. [CrossRef]

47. Chen, J.; Xu, Q.; Song, Y.W. Characterization of the in situ growth manasseite/carbonates composite conversion film on $\mathrm{Mg}_{2} \mathrm{Zn}$ alloy. Mater. Lett. 2015, 150, 65-68. [CrossRef]

48. Chen, J.; Song, Y.W.; Shan, D.Y. Influence of alloying elements and microstructure on the formation of hydrotalcite film on Mg alloys. Corros. Sci. 2015, 93, 90-99. [CrossRef] 
49. Zhang, F.; Liu, Z.G.; Zeng, R.C. Corrosion resistance of Mg-Al-LDH coating on magnesium alloy AZ31. Surf. Coat. Technol. 2014, 258, 1152-1158. [CrossRef]

50. Zhang, F.; Zhang, C.L.; Song, L. Corrosion of in-situ grown MgAl-LDH coating on aluminum alloy. Trans. Nonferr. Met. Soc. China 2015, 25, 3498-3504. [CrossRef]

51. Starljngke, K.E.; Han, M.S. Thermo data refined for LPG-14. Mixtures. Hydrocarb. Process. 1972, 51, $129-132$.

52. Liauo, C.S.; Huang, J.C. Relationship between apparent and true activation energies. Scripta Mater. 1998, 39, 873-879. [CrossRef]

53. Zhang, T.; Shao, Y.W.; Meng, G.Z. Corrosion of hot extrusion AZ91 magnesium alloy; I-relation between the microstructure and corrosion behavior. Corros. Sci. 2011, 53, 1960-1968. [CrossRef]

54. Song, G.L.; Atrens, A.; Wu, X.L.; Zhang, B. Corrosion behavior of AZ21, AZ501 and AZ91 in sodium chloride. Corros. Sci. 1998, 40, 1769-1791. [CrossRef]

55. Cao, Y.; Li, G.; Li, X. Graphene/layered double hydroxide nanocomposite: Properties, synthesis and applications. Chem. Eng. J. 2016, 292, 207-223. [CrossRef]

56. Alibakhshi, E.; Ghasemi, E.; Mahdavian, M.; Ramezanzadeh, B. A comparative study on corrosion inhibitive efect of nitrate and phosphate intercalated Zn-Al-layered double hydroxides (LDHs) nanocontainers incorporated into a hybrid silane layer and their efect on cathodic delamination of epoxy topcoat. Corros. Sci. 2017, 115, 159-174. [CrossRef]

57. Song, G.L. Corrosion behavior of magnesium alloys and protection techniques. Surf. Eng. Light Alloy. 2010, 3-39. [CrossRef]

58. Zhang, T.; Li, Y.; Wang, F.H. Roles of beta phase in the corrosion process of AZ91D magnesium alloy. Corros. Sci. 2006, 48, 1249-1264. [CrossRef]

59. Fajardoa, S.; Frankel, G.S. A kinetic model explaining the enhanced rates of hydrogen evolution on anodically polarized magnesium in aqueous environments. Electrochem. Commun. 2017, 84, 36-39. [CrossRef]

60. Thomas, S.; Medhekar, N.V.; Franke, G.S.; Birbilis, N. Corrosion mechanism and hydrogen evolution on Mg. Curr. Opin. Solid State Mater. Sci. 2015, 19, 85-94. [CrossRef]

61. Song, D.; Ma, A.B.; Jiang, J.H. Corrosion behaviour of bulk ultra-fine grained AZ91D magnesium alloy fabricated by equal-channel angular pressing. Corros. Sci. 2011, 53, 362-373. [CrossRef]

(C) 2019 by the authors. Licensee MDPI, Basel, Switzerland. This article is an open access article distributed under the terms and conditions of the Creative Commons Attribution (CC BY) license (http:/ / creativecommons.org/licenses/by/4.0/). 